\title{
The pragmatics of manipulation: exploiting im/politeness theories
}

\section{Sandrine Sorlin}

\author{
Aix Marseille Univ, LERMA, Aix-en-Provence, France
}

\section{Introduction}

Manipulation has been studied in empirical studies by socio-psychologists since the end of the 1960s and has brought to light famous techniques that can exert an influence on human behaviour (especially in the fields of marketing and advertising). The art of controlling others by having them do something that is not in their interest has indeed a long history of experimental testing: we can name the famous 'foot in the door' tactic tested by Freedman and Fraser (1966), the 'door-inthe-face' strategy (Cialdini et al., 1975), the importance of 'the touch' in manipulative strategies (Smith, Gier and Willis, 1982, Goldman, Kiyohara and Pfannersteil, 1985), the manipulation of 'cognitive dissonance' (Festinger, 1957), the 'obedience to authority' testing (Milgram, 1963), and other 'weapons of influence' based on factors that affect decisions such as 'reciprocation' and 'liking' (Cialdini, 1984, 2001) or engagement through preparatory acts (Joule and Beauvois, 2002, Beauvois, 2011).

But in these studies the focus has been more on the factors that influence human behaviour than on discursive manipulation - the language of manipulation having been only marginally tackled (see Guéguen, 2011). Scholars in the field of Critical Discourse Analysis who have been interested in manipulation in discourse do so with the aim of exposing the deceptive tactics used by dominant groups. Fairclough (1989:6) for instance defines manipulation as "a devious way to control the others" and van Dijk (2006:359) as the 'illegitimate' domination of one powerful group over others with the goal of maintaining social inequality. Van Dijk (2006) has taken a cognitive turn, analysing manipulation in a triangular theoretical framework (discourse, society, cognition), showing how and why some linguistic properties can be more effective than others in the manipulation of the human mind. A theory of manipulation that would not take a cognitive perspective would indeed miss some important aspects of how the mind is (more or less covertly) manipulated into compliance. Addressing cognitive issues that Gricean and Neo-Gricean approaches seem to have no interest in, some pragma-cognitivists have recently delved into the 
issue of manipulation in very interesting ways, in their study of the cognitive processes involved while interpreting manipulative discourse. Basing their work on relevance theory (namely Sperber and Wilson, 1995), Saussure $(2005,2014)$, Herman and Oswald (2014), Maillat and Oswald (2009) and Maillat (2013, 2014) have shown how human cognition is tampered with by manipulators.

Van Dijk's triangular analysis of manipulation as well as the pragmacognitivists' focus on tampered cognition seem however to leave aside a major aspect of manipulation that this paper is more specifically concerned with (although cognitive aspects cannot be discarded): they both put aside either social and/or psychological aspects pertaining to the social goals of the interlocutors and the psychological traits of each person involved in an interaction ${ }^{1}$ - though this aspect has been partly covered by social cognition interested in such phenomena as popular belief and credulity (see for instance Clément 2006). What is overlooked in cognitive and Critical Discourse approaches is indeed the psychological aspect of manipulation that often consists in exploiting the target's weaknesses or what Baron (2003:44) calls "emotional needs". The approach in this paper thus differs from standard accounts of manipulation that solely focus on the informational/belief-based/cognitive impact of the phenomenon; manipulation is here defined in terms of the a) ulterior motives behind a communicative effort and of the b) course of actions the discourse generates. As expounded below (3.2), defining manipulation in conversational exchanges on that actional level allows taking into consideration both the Speaker's extralinguistic motives and goals and the perlocutionary effects of discursive manipulation. Indeed, the latter crosses the boundary between what a linguistic form can trigger during its interpretation (as represented by the Hearer) and its (perlocutionary) effects in terms of ensuing action.

After exposing the treatment 'manipulation' has received in traditional philosophy of language and some argumentative/persuasion theories (section 2.1) and attempting to define its borders (2.2), this paper will show to what extent Manipulative Discourse (henceforth MD) can in fact be placed within a Gricean framework while going beyond it to include the discursive strategies of influence that Grice (1989:28) admitted his Cooperative Principle was too limited to integrate.

\footnotetext{
${ }^{1}$ To be fair, CDA is not concerned with interpersonal pragmatics and interaction as I am in this paper.
} 
Concentrating on the more (socio)psychological pragmatic aspects of manipulation implies a focus on the Speaker and the Hearer ${ }^{2}$ as individuals with their specific personality traits and egocentric agendas. To do so, it will be shown in 4.1 that politeness theory based on Goffman's (1967) notion of face has a key role to play in explaining these phenomena, if and only if politeness theory rebalances its primarily altruistic orientation - conceiving politeness as a means to attend to the Hearer's face. A balance should indeed be reinstated between the 'cooperative' aspect of politeness that has been the object of much scientific investigation and a 'manipulative' exploitation of the same maxims of politeness involving a (more or less covert) focus on the Self that has not been sufficiently researched (see below).

Three manipulative exploitations will then be singled out (4.2 to 4.4), based on a fictional corpus set in a political context, the popular American TV series House of Cards (Netflix 2013-2017): 1. The use of politeness to enhance the Other's face, and in doing so, to conceal the Speaker's self-interest (and protect her own face). 2. On record Self-Face Threatening Act (Chen, 2001) that involves a cost to Self in view of a (postponed) higher gain (for Self). 3. Self-enhancement that paradoxically has an impact on the Other's sense of self-esteem. What these strategies show is that both politeness and impoliteness can be used conjointly to achieve the Speaker's "perlocutionary purposes" (Gu, 1993). In fact, MD operates by maintaining surface courtesy (for the aim is not to attack the Hearer but to obtain something from her) using at times what could be deemed impolite means whose underlying goals are to dominate the Other and drive the course of the conversation in a way that is relevant to the Self.

\section{The whole spectrum of manipulative discourse}

\subsection{Manipulation as failed communication?}

Dominant communicative theories are predicated on a philosophy of language based on cooperation between rational and reasonable human beings. In this theoretical context, manipulation has very often been seen and discarded as loss or failure of communication. Scholars who have taken an interest in discursive manipulation have based their study on the presupposition that manipulation is some

\footnotetext{
2 The pair Speaker $(\mathrm{S}) /$ Hearer $(\mathrm{H})$ will be used to refer to interlocutory positions, as well as the couple Self $(\mathrm{S}) / O$ ther $(\mathrm{O})$ when dealing more specifically with self and other (psychological) attributes.
} 
would-be persuasion, that is a form of what Mills (1995:100) calls "persuasion manquê". Philosophy for a start has defined it in ethical terms as a perversion of communication. While persuasion is at the heart of human communication, manipulation supposedly belongs to its darkest fringes as it falls short of the ideal of truthful and rational cooperation. This rationalist bias is no new theoretical stand. At least since Plato who found fault with the sophistic practices, some philosophers of the rhetorical tradition have denounced the potentially wrongful use of language to mislead rational thinking (logos) and arouse wrong passions (pathos) (see Guérin, Siouffi, and Sorlin, 2013). More recently the theories of manipulation put forward by philosophers are still underpinned by the same yearning for irenic persuasion and transparent communication: Gorin (2014) suggests adding a fifth maxim ('be transparent') to Grice's Cooperative Principle while Scanlon's (1998) moral principle ('Principle M') similarly denounces the moral wrongness of misleading the addressee about our genuine intentions. The philosophical project of German philosopher Jürgen Habermas $(1987,2006)$ could be said to be in line with this aspiration to ethical communication in its attempt at extracting the conditions of possibilities of successful understanding and agreement between human beings. Similarly, scholars working in argumentation and dialectics also define manipulation as a form of persuasion that has gone wrong as it fails to abide by what pragma-dialecticians call the right 'code of conduct' (van Eemeren and Grootendorst, 2004). Van Eemeren (2005) for instance perceives manipulative discourse as fallacious discourse that 'derails' from the ethical and rational means of persuasion.

The aim of this paper is to show that the study of manipulation has been hampered by this 'truth bias' and what Galasiński (2002:3) calls, in The Language of Deception, its attendant 'claim to morality' that are at the heart of dominant communication theories. I contend that manipulation is more pervasive ${ }^{3}$ than one supposes it to be and should therefore be seen as a worthy object of study that can

\footnotetext{
3 I agree with one reviewer's very pertinent comment that the fact that manipulation is defined elsewhere in reference to communicative norms does not make it less pervasive a phenomenon, just as flouting Gricean maxims is inferentially richer than their strict observance. But bringing manipulation to center stage - rather than seeing it as a consequence of norm-breaking - allows me to reverse the usual norm/margin dialectic that has dominated studies of manipulation and to present the latter as a major phenomenon in itself.
} 
throw light on so-called 'normal' aspects of communicative interaction. Rather than seeing it as the exception that needs to be put aside as not fitting the communicative rule system, it will be presented as what exploits the very possibilities of the conversational principle. So rather than throwing the baby with the theoretical bath water, this paper claims that although MD has its own specificities, it relies on cooperation (Grice, 1989) and politeness strategies (Brown \& Levinson, 1987, Leech, 1983 , 2014). But being themselves founded on the same truth bias and morality claim that have just been denounced, these theories need to be amended: I will first evince why Grice's Cooperative Principle is exploited - rather than subverted - in manipulation and why it must be extended to encompass the manipulator's covert goals. Besides I will demonstrate that MD is parasitic on both politeness and impoliteness strategies to various degrees, which makes it a hybrid form questioning Brown and Levinson's clear-cut categories (positive and negative politeness) on the one hand and the exclusive opposition between politeness and impoliteness on the other - dichotomies that have been reconsidered in more recent theories of (im)politeness (Locher and Watts, 2005, Culpeper and Terkourafi, 2017 for instance).

But before doing this, one must try to define the "fuzzy borders" of manipulation (Saussure and Schulz, 2005:3) to establish the scope of manipulative discourse.

\subsection{A continuum with possible overlaps}

First of all, manipulation can sometimes be used for 'ethical' purposes in a way that is sometimes overlooked by moral philosophy: manipulative means can be used to help a friend do something for her own good where more rational means of persuasion would fail on her - in this specific case then, manipulation is getting someone to do something that is in her interest. But what is the difference between persuasion and manipulation as both seem to aim at winning over Hearers/Readers to act in a way or hold a viewpoint as desired by its producers? It must be admitted that persuading cannot be an entirely neutral act - only for the simple fact that language is always 'perspectivated' (Danler, 2005:46), but in persuasion it seems that both Speaker and Hearer have access to all the information needed to exchange arguments. Persuasion would consist in bringing the Hearer to consent to the persuader's viewpoint, using means that would not try to conceal or unduly 
foreground some information. In Maillat's (2013) cognitive approach, as opposed to manipulation, persuasion makes no attempt at controlling the 'Cognitive Environment of the hearer' $\left(\mathrm{CE}^{\mathrm{H}}\right)$ :

Persuasion would then correspond to a situation where the speaker tries to get some information into the $\mathrm{CE}^{\mathrm{H}}$ by getting a proper visa for it, while manipulation corresponds to an attempt at smuggling some information into $\mathrm{CE}^{\mathrm{H}}$ ('getting past [the hearer's] defences according to Sperber et al. 2010) (Maillat, 2013:195).

In persuasion it seems to be possible for the Hearer to select (at least) another relevant context in which the Speaker's utterance could be interpreted. Thus what manipulators tamper with, cognitively speaking, is the Hearers' interpretative possibilities, limiting their "freedom of interpretation" so to speak. They may for instance bring Hearers to "shallow process" some contextual assumptions that would have been pertinent to interpret the manipulator's utterance differently and bring out her attempt at deception.

However, persuasion is hardly a hard-edge concept that can easily be demarcated. While pointing at the difficulty in providing a definition for "persuasion", O'Keefe (2002) yet comes up with six common features of what would be "core persuasion" or "paradigm cases" of persuasive communication: success, a goal, intent to reach it, freedom ('free will, free choice and voluntary action') for the persuadee, use of language to do so, change in mental state (rather than direct influence of conduct). These features are united in the definition he ventures: "a successful intentional effort at influencing another's mental state through communication in a circumstance in which the persuadee has some measures of freedom" (2002:5). Manipulation shares with persuasion at least four features: it implies the success of the entreprise. If one can say "he tried to manipulate me but failed", one cannot say "he manipulated me but failed". Success thus seems "embedded" in both attempts at influencing. Manipulators have a goal in mind and every intention of achieving it. They will try to obtain that effect through language (rather than physical force). The fifth feature concerning the communicative effects does not totally fit MD: persuasion involves trying to act on the persuadee's beliefs and attitude (which is only a "precursor to a change in behaviour", O'Keefe 2002:4). 
As noted above, if manipulation can be "belief-based" in the sense that it aims at talking the victim into adopting the manipulator's beliefs and desires, it does not only consider a change in "mental state". As will be demonstrated below, it has "perlocutionary purposes" that involve bringing the Hearer to take some actions as desired by the Speaker.

The last feature concerns an aspect already highlighted in cognitive accounts of manipulation previously mentioned: the amount of freedom the addressee is granted. ${ }^{4}$ O'Keefe gives the following example:

Consider, for example, a circumstance in which a person is knocked unconscious by a robber, who then takes the victim's money; one would not (except humorously) say that the victim had been 'persuaded' to give the money. By contrast, being induced by a television ad to make a donation to a charitable cause is obviously an instance of persuasion. (O'Keefe, 2002:4-5)

Indeed, the first instance would rather qualify as physical coercion. However, it seems to me that in between the example of "obvious" persuasion given by O'Keefe - note that even in this case persuasion could well be achieved through manipulative means - and physical coercion, there is room for a whole range of strategies of influence that the continuum below drawn from Sorlin (2016) serves to exemplify. Manipulation could be conceived on a spectrum between persuasion on the one hand and coercion on the other, bearing in mind that manipulation leaning on the side of persuasion would tend to be more belief-based than it is in coercive manipulation. In the latter case, the manipulator would seek to coerce the victims into acting in a certain way (through linguistic/pragmatic - not physical - means) rather

\footnotetext{
${ }^{4}$ Commenting on the potentially manipulative aspects of modern communicative 'nudging'4, Wilkinson (2013:351) comes to the conclusion that if a nudge contains what he calls "an escape clause", that is the possibility to "opt out", the nudge cannot be deemed manipulative. So manipulation would imply a covert intent on the part of the manipulator who would purposefully not reveal the whole story to the victims and thus make it difficult for them to "opt out". It is true that what I call "prototypical manipulation' has to operate covertly if it is to work as the pragmatic function of manipulating can hardly be revealed in a performative way: you cannot say "let me try to manipulate you" for instance without engaging in what Cholbi (2014:202) calls "a performative contradiction". ${ }^{4}$
} 
than coercing them into adopting the Speaker's beliefs. For Wood (2014:31), coercion indeed occurs where choices are "made for you" whereas manipulation is a means to "influence" free choice (in a way that suits the manipulator). The continuum is represented in figure 2.2.1.

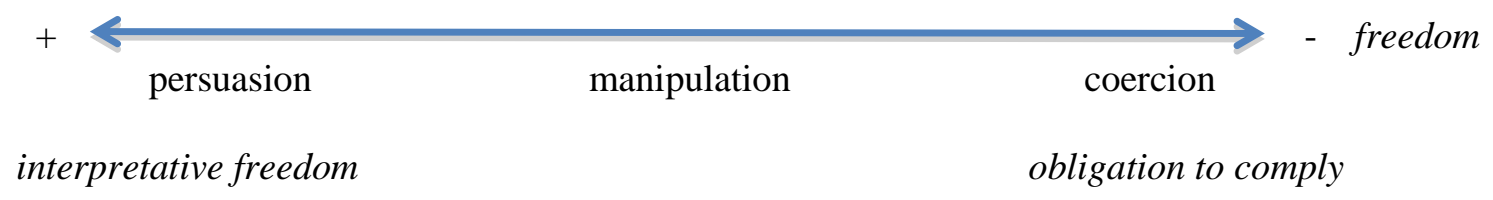

2.2.1 The manipulative spectrum

What the continuum enables me to show is that there can be no clear line separating persuasion and manipulation in that, in many cases, persuasion can be said to be a kind of manipulation. In this model, "paradigm persuasion" (on the left-hand side of the continuum) represents an ethical communicative ideal that all exchanges should strive for but often fall short of. Persuasion can indeed easily morphs into manipulation if the right context is set up, this is why I have argued that manipulation is more pervasive than one might think in a variety of practical contexts. Moving from persuasion to prototypical manipulation in the centre is moving towards more and more 'illegitimate' means of influence: lying being the paradigm case of manipulative communication. More generally, deceiving 5 (including masking or disguising information, confusing the Hearer or lying to her if only by omission) embodies a prototypical concealment of the manipulator's intentions. But as the continuum aims at showing, Manipulative Discourse goes beyond simple covert deception to include cases that can lean on either side of the spectrum. MD can indeed make its underlying coercion more or less visible (drawing here closer to the right-hand side of the spectrum). It can impose some form of pressure on the target (the act becomes here less covert than in deception as the victim may be aware of the underlying discursive coercion). Manipulating the number of options available to the target is a

\footnotetext{
${ }^{5}$ Having reviewed the whole literature on the matter, Masip et al. (2004:148) offer their own definition: "deception is the deliberate attempt, whether successful or not, to conceal, fabricate and/or manipulate in any other way factual and/or emotional information, by verbal and/or nonverbal means, in order to create or maintain in another or in others a belief that the communicator himself or herself considers false."
} 
way to (more or less overtly) induce her to yield for instance. The Speaker's manipulative move remains implicit but can be inferred by the target - who may have to comply in cases for instance when the claimant has 'reward power'6 over her. In addition to (covert) deception and (more or less overt) pressuring moves, there is a last category of manipulative acts that this paper will more specifically be concerned with: the play on the targets' inner desires or ambitions, weaknesses or vulnerabilities. Manipulation is here part of what, in a moral philosophical perspective, Baron (2003:44) calls "taking advantage of another's emotions or emotional needs". This category needs to be addressed in more pragma-linguistic terms however, starting with Gricean pragmatics in the following section.

\section{Cooperating without cooperating: the paradox of manipulation}

\section{1 'Unostentatious violations'}

It could be thought at first sight that manipulation embodies the opposite of cooperation. In the fictional corpus under study (the data are taken from the first three seasons of the American political TV series House of Cards), the protagonist, Frank Underwood, is ready to do anything to get to the top of the American political ladder. Using deceptive strategies, he can be un- or over-informative if it suits his purpose, he often withholds information (against Grice's maxim of Quantity), he disseminates rumours (breaking the maxim of Quality), he controls the flow of conversation, imposing what is relevant and what is not (freely using the maxim of Relation in his own interest), he is unclear and indirect when he needs to get away with accountability and does not hesitate to insinuate in most ambiguous ways (taking the opposite stance of the maxim of Manner).

However, manipulators do count on the addressee's belief in their abiding by the Cooperative Principle. There are no inherent linguistic and pragmatic markers of manipulation per se (Saussure, 2005:119). In fact, MD consists in 'unostentiatiously

\footnotetext{
${ }^{6}$ Raven (1959:263) defines 'reward power' as predicated on the perception that the Speaker "has the ability to mediate rewards" for the Hearer. This is one among other categories of power such as expert power, legitimate power and referent power. See also Spencer-Oatey 2008:34-5.
} 
violating' the CP (Grice, 1989:30) in a way that cannot be grasped by the Hearer. ${ }^{7}$ As Mooney (2004:918) indicates, it is impossible for the Hearer to spot manipulative discourse as it seems to leave the CP 'intact'. In other words, Hearers assume that Speakers are being cooperative. Lying is a case in point - Levinson (2006:54) sees it as 'parasitic' on the act of asserting. For a lie to be successful, the person that is lied to must believe that the liar respects the maxim of Quality, otherwise his intention of lying would be revealed and the lie exposed. An example from House of Cards will make clear the difference between the perlocutionary goal of lying (making the Hearer believe this is the truth and act accordingly) and the Speaker's contrary/insincere belief. ${ }^{8}$ At the end of the second season, Frank wants to reassure the president about potentially compromising elements - regarding his counselling sessions with his wife appearing in his travel logs that are due to be scrutinized by the general prosecutor (in view of a possible impeachment). First addressing the audience in an aside, he then addresses the president:

Francis [aside]:

[to the president]:
He's worried about his marriage counselling, as he should be.

If you're worried about your marriage counselling, you shouldn't be. $(2.24,26: 31-26: 37)^{9}$

In House of Cards, the viewer can easily grasp the main character's covert intentions as he confides his thoughts and goals in asides.

The protagonist also capitalizes on pragmatic inferences (implicatures) drawn by the Hearer in normal exploitation of the CP. In the extract below from season 2, Frank has become Vice President. He is trying to persuade Michael Kern to help the president who is faced with an impeachement vote - Kern is President Garret

\footnotetext{
${ }^{7}$ McCornack (1992:5-6) goes in the same direction with his Information Manipulative Theory (IMT) showing that the Hearer must think the Speaker is conforming to the CP at the very moment she violates it.

${ }^{8}$ Hence its paradoxical position in speech act theory: in order for the speaker's lie to succeed, the sincerity condition must be infringed. In other words, the illocutionary act of asserting is unsuccessful since it does not abide by the sincerity condition (Reboul, 1994:297).

9 In all references to the series, the season is given first, followed by the chapter number and the exact time location.
} 
Walker's former Secretary of State that the president has had to let go in the first season because of Kern's past anti-Israelian allegations brought up by the press. But while trying on the surface to convince Kern to support President Garret, Vice President Underwood leads him to get the point that doing the opposite would bring about a positive outcome for Kern:

Michael: $\quad$ To be honest, l'm not particularly inclined to be doing Walker any favours.

Frank: $\quad$ Now, Michael, I know he revoked your nomination.

Michael: $\quad=$ He didn't fight for me at all=

Frank: He had just been elected. He wasn't in a position...

Michael: $\quad$ Wrong, he had a clear mandate. He was in a strong position to defend me.

Frank: $\quad$ You're right. If I'd been president, I wouldn't have given in so easily. [...] The truth is I wouldn't have nominated you for Secretary of State in the first place. I would have nominated you for Secretary of Treasury. Because your expertise in economics is even better than your grasp on foreign affairs. Now, if I were president, you'd be Secretary of Treasury.

Michael: If YOU were president.

Frank: $\quad$ That's right. $(2.26,31: 55-32: 50)$

That Kern grasps the point the Speaker is implicitly making (or gets it from the situation $\left.{ }^{10}\right)$ is visible in his repetition of Frank's phrase with the marked emphasis on 'you': "If you were president". Kern manages to decode what Frank is implicitly asserting here: doing the opposite of what is explicitly stated he should do at the beginning of the extract (support the president) would result in his becoming Treasury Secretary under Frank's presidency (impeachment would indeed result in the VP becoming president pro tempore). Frank's 'that's right' seems to indicate that Kern has correctly decoded the indirect promise. The VP cannot openly voice his secret opposition to the President, so he invites Kern to interpret a hypothetical that

\footnotetext{
10 I agree with Haugh (2007:96) that speaker intention is not necessarily the only resource from which to make inferences. What the Hearer understands is necessarily 'co-constituted': an implicature is "inferred from what is said in the situation as a whole (more than made by the hearer about the speaker's intentions)."
} 
is contextually oriented towards the past (use of the past perfect in If'd been President) as hypothetical about future events.

The VP is talking Kern into taking a certain course of action using indirect means definitely flouting the maxim of Manner. Manipulation is thus 'parasitic' on the Gricean maxims. Kern cannot be said to be 'manipulated' in a prototypical sense here though, since Frank makes his ultimate goal clear - although implicitly. Besides, agreeing to do as Frank wishes will end in a win-win situation for both of them, so Kern is not talked into doing something that will only serve the manipulator's interest. Yet the manipulative "extra-linguistic" intention lies in the VP's intent to underhandedly bring Congressmen to vote against the President while assuring the latter of his absolute support.

Hence the paradox of MD, it is cooperative while being uncooperative in a way that will be further detailed in the next sub-section.

\subsection{Exploiting and going past the $\mathrm{CP}$}

Cooperation can be satisfied at a linguistic level while failing to obtain at a social one. Conflicts (Searle, 1998:120), quarrels (Pfister, 2010:1273) or insults (Bousfield, 2008) imply some linguistic cooperation if only to "communicate a lack of cooperation in a social sense" (Bousfield, 2008:29). Manipulation is based on the same assumption of linguistic cooperation (through the exploitation of the pragmatic rules of conversation) while being socially uncooperative (see Lumsden, 200811).

In fact, Grice himself was conscious that his scheme needed to be extended to integrate the different types of influence one can exert over Hearers in having them take a certain course of action over another:

I have stated my maxims as if this purpose were a maximally effective exchange of information; this specification is, of course, too narrow and the scheme needs to be

\footnotetext{
11 Lumsden (2008:1900) puts it very simply by separating two claims: "We could separate two claims that Grice makes about conversations:

1. a claim about the explanation of the use and detection of implicatures [...]

2. a claim about the nature of conversations: that they are usually cooperative.

It is possible to attack claim 2 while maintaining claim 1".
} 
generalized to allow for such general purposes as influencing or directing the actions of others. (Grice, 1989:28)

Accounting for "general purposes" (among which manipulative moves), one needs to take into consideration what Thomas (1986) calls "social goals" and Gu (1993) the "ultra-linguistic' goals" of the Speaker (see also Attardo, 199712, Sarangi \& Slembrouck, 1992, Capone, 2001). Gu (1993:188) for instance claims that there are two broad kinds of cooperation working at two (interconnected) levels, "the level of Ssending/H-interpreting" (where the CP is valid) and a "rhetorical" level that includes extralinguistic perlocutionary purposes (performed through diverse illocutionary acts) that he defines thus: "the purpose(s) of the speaker s/he attempts to reach in performing an illocutionary act". 13 In other words, "rhetorical cooperation" is concerned with the way the Speaker aims at influencing cooperation with the Hearer and the way the latter serves the purpose of the Speaker's goals. Although Gu does not focus on manipulation, MD clearly belongs to the level of "rhetorical influence". However, as Attardo (1997:767) notes, Gu's account is focussed on the "altruistic motives" of the Hearer's cooperating to satisfy the Speaker's goals, leaving little space for other "principles governing our actions" such as self-interest or selfpreservation ${ }^{14}$, which is at the heart of MD.

For Chapman (2011:132), the need for an extended scheme as called for by Grice himself (that would include manipulative strategies) has been taken up by politeness theory whose aim is to "explain the social motivations for speaking to each

\footnotetext{
12 Attardo' Perlocutionary Cooperative Principle (PCP) consents that "linguistic behaviour" contributes to a small degree to the overall exchange: "the PCP acknowledges that what is cooperative depends on the goals of the participants in the exchanges and thus cannot be established a priori”.

13 It must be noted that the linguistic level can be goal-oriented as Lumsden (2008:1901) qualifies: "it may be preferable to say that the cooperative principle does indeed only apply to linguistic cooperation but in some cases, what counts as a maximally effective exchange of information is relative to that extra-linguistic goal."

14 "as Gu notes, the hearer will incur some cost in performing whatever is required for the success of the speaker's goals. This is clearly in violation of the self-interest (rationality) principle discussed above" (Attardo, 1997:777-778).
} 
other as we do". The aim of this paper is to show to what extent politeness theory can account for these "general purposes" (Grice, 1989:28). Indeed, as the next section will evince manipulative strategies are parasitic on positive and negative politeness strategies as inventoried by Brown and Levinson's seminal work (1978). However, because politeness has (originally) tended to suffer from the same truth bias and its attendant claim to morality as traditional philosophy of language, it has remained altruistic at its core. Although the authors claim they were interested in both Self and Other, Brown and Levinson's superstrategies aim at avoiding conflicts by smoothing out potential face-threatening acts towards the Other. Leech $(1983,2014)$ defines politeness as 'communicative altruism' aiming primarily at saving the Other's face - although he makes clear that this altruistic gesture has an egoistic counterpart, since it also reverberates positively on the Speaker's face, but this seems to be rather a side-effect of a first and foremost 'you-oriented' attitude: "in polite utterance, the other person is considered the beneficiary and the speaker is not" (Leech, 2014:6). In line with research that has expanded Brown and Levinson's theory namely rapport management theory (Spencer-Oatey, 2007) and relational identity (Arundale 1010, Spencer-Oatey, 2007, 2011) highlighting the co-construction of faces in interactions, considering presentation of both Self and Other, the next part will bring the margins of politeness theory back to centre stage.

\section{Exploiting politeness strategies}

\subsection{Theoretical rebalancing}

This paper adopts the opposite stance of traditional conceptions of politeness which conceive it as a means to protect the Hearer's face (and the Speaker's own in so doing) in pursuit of social cohesion and harmony. It throws light on what is often left in the dark alleys of strategic communication: the use of politeness tactics to manipulate the Other into doing something that is (mostly) in the Speaker's interest. Foregrounding the concern with the Other has inevitably led to the backgrounding of the more ego-centered strategic use of politeness. A few authors have attempted to rebalance the theory though. Chen (2001) for instance has proposed a model of 'selfpoliteness' that consists in protecting (or threatening) Self-face, setting up a series of Self-centered strategies that are (more or less) modelled on Brown and Levinson's 
superstrategies. ${ }^{15}$ This aspect will be illustrated in 4.3 but it will be shown in 4.4 that the 'negotiation' of self in interactions can go beyond concerns for Self-face wants. Chilton (1990) was among the first to highlight the possibility to use politeness for strategic means and specific agendas in political discourse, enhancing one essential feature of politeness strategies: doing politeness can aim either at cohesion or domination. What's more, the very same linguistic means can be used for either: " $A$ major point is that the same linguistic resources can serve both functions, and it is this that makes linguistic domination possible" (Chilton, 1990:205). In Chilton's wake, speaking of "two-faced" 16 politeness phenomena, I see self-centered and othercentered politeness strategies as two united sides of the same coin: either politeness serves explicitly personal strategic ends (from which the other may or may not benefit) or it aims at smooth cooperation with the Other (which can indirectly reflect positively on the Self). Like a coin, the emphasis may either be on the Other (communicative altruism) or on the Self (self-politeness) depending on what the Speaker intends to show, but if the coin shows altruism, it does not mean that selfinterests do not lurk from the back of the coin: there are indeed many cases where the apparent 'you-first' orientation masks an I-first orientation, altruism serving as a mask for fulflling self-centered goals.

Sifianou (2012) gave a hint of this possibility in her study of disagreements. Reconsidering the potential merits of disagreements - that are most often presented as what should be avoided, the desire to agree being seen as primary, she also shows that agreements can be deemed manipulative when they masquerade as altruism: "such contentions ignore the possibility that even agreements may be face threatening if, for instance, they are interpreted as insincere, manipulative or ingratiating" (Sifianou, 2012:1559).

Indirect illocutions - going 'off record' in Brown and Levinson's terms - have usually been conceived as 'more polite'. However, Chilton (1990) and Ermida (2006) show that in the ambiguous space they create, politeness can be exploited to the Speaker's advantage. Highlighting the multi-functionality of politeness in her study of O'Brien's control of Winston Smith in Orwell's Nineteen Eighty-Four, Ermida evinces to what extent indirectness and positive politeness strategies can be used to mask

\footnotetext{
15 Chen's model does not distinguish between positive and negative politeness (2001:96)

16 "politeness has both a conflictual and a cooperative face" (Chilton, 1990:222).
} 
coercion. Being polite becomes a way to 'attract' and to subject: "like Chilton (1990), I also think that a positive and cooperative reading of politeness misses some important uses of the phenomenon in social interaction. In particular, it fails to grasp the fact that politeness can be 'ill-intentioned and aggressive' - and, as seen in O'Brien's manipulation of Winston, can be aimed at enhancing power and control" (Ermida, 2006:860).

However, my point here is that such strategic use of politeness 'tactics' is not necessarily meant in an 'aggressive' way. A difference should be made here with politeness that hides a form of aggressiveness - what Kerbrat-Orecchioni (2010) calls 'polirudeness' or Agha (1997) 'topic aggression' that consist in using surface politeness as a veil for aggression (see also Fracchiolla, 2008, Fracchiolla et al., 2013 for examples of attack of the Other without seeming to do so). I contend that politeness-based MD is much more common practice in every day professional work and also private interactions.

Imagine you arrive in the morning in your office and compliment your secretary on the work done so far or about the lovely colour of her hair, it might well be a (nonaltruistic) way of implying 'keep up with the good work, I expect no less' or a way to soften the bitter pill that follows (today's work that needs to be done). Manipulative politeness (that is the egocentric use of politeness to further one's own objectives) ${ }^{17}$ can thus be a way of maintaining polite work relations (even while keeping up an underlying pressure) - it is thus 'positive' in the sense that it is better than unmitigated orders and work relations based on fear and explicit domination. It can be interpreted as polite hypocrisy if the complimented person knows that the compliment is goal-oriented (and can complain about such form of ingratiation to her colleagues afterwards) but it has the merit of maintaining good work relationship (on the surface at least) even though nobody is dupe to the little human comedy. ${ }^{18}$ The line with deceptive manipulation would be crossed if manipulation consists in deceiving the Hearer into acting in a way that will be contrary to her own interest -

\footnotetext{
17 This would correspond to what O'Driscoll (1996:17) calls 'conscious strategy' (as opposed to the routine use of politeness) where Gu (1990:242) speaks of 'instrumental' versus 'normative' politeness. 18 See Holmes and Stubbe, 2014 for the study of interactions between subordinates and bosses in the workplace, where the latter use politeness strategies to conceal power difference and achieve organisational goals, transforming coercive power into "collaborative power" for instance.
} 
Frank's manipulative lie to President Garret mentioned above (3.1) is a case in point. Coercive manipulation (leaning on the right-hand side of the continuum) will not hesitate to use a higher degree of impoliteness when approaching the Other, with the possibility of threatening her into compliance for instance (see Sorlin 2016 for a correlation of the persuasion-manipulation-coercion continuum within an $\mathrm{im} /$ politeness framework).

Although Leech (2014:4) is aware of the inevitability of self-interested politeness, he seems to show little interest for it:

Inner feelings are not the concern in this present study of politeness: it is concerned, rather, with politeness as an observable behavioural phenomenon. Hence when I say politeness is 'communicative altruism', this should not be misunderstood: the 'altruistic meaning' conveyed via communication should not be equated with genuine altruism, where someone does or says something unselfishly, for the sake of some other person(s) - to extend a helping hand to them. Often communicative altruism and genuine altruism do coincide, but it is not difficult to imagine or recall cases where they do not.

Specifically interested in cases where communicative and genuine altruism do not 'coincide', I claim that the extra-linguistic goals that Leech is not concerned with put to the test politeness theory in calling for a more important focus on the Speaker than theories of Gricean inspiration have - which, as Kesckes (2010:52) rightly puts it, is a paradox since Grice himself "emphasized speaker's meaning". ${ }^{19}$

In the analyses that follow, the emphasis is put back on the Speaker (as well as the Hearer) as individuals endowed with their own personality traits and selfish agendas. What will be successively highlighted is the diverse politeness tactics used by some characters in House of Cards to convince and/or coerce the Other (along the whole gamut of MD illustrated in figure 2.2.1) to do what they want her to do in order to further their own personal interests, first by using traditional politeness strategies that attend to the Other (4.2), second with an instance of 'self-politeness'

\footnotetext{
19 Gricean pragmatics has remained Hearer-oriented in that the focus has been on the recovery/recognition of Speaker's meaning and intention (while Relevance Theory has been interested in Hearers' interpretation and reconstruction of the Speaker's assumptions) (Kesckes, 2010:53).
} 
(4.3) and lastly with strategies of Self-enhancement that are meant to 'entice' the Other into compliance (4.4).

\subsection{Egocentrism masquerading as altruism}

MD is indeed parasitic on the politeness strategies defined by Brown and Levinson (1987) and Leech $(1983,2014)$. In the extract below, Frank must restore harmony and reduce conflict with angry bereaved parents whose daughter was killed while driving: she was texting a friend, joking about the form of the Peachoid water tower in Gaffney. Frank fought so hard for the tower to be built when he was trying to get elected in the $5^{\text {th }}$ congressional district of South Carolina that he is somewhat blamed for her death by the Gaffney people. The parents intend to sue as there were no safety billboards on the road announcing the presence of the tower. Frank's name could be stained in this case, so he resolves to go to his home state to solve the problem. He receives a very cold welcome from the grieving family. He then decides to ask the reverend if he could read a passage from the bible in the upcoming Sunday church service. Of course, Frank does not read the agreed text, using the floor instead to give a speech whose covert goal is to bring the parents to drop the charges while passing for a sympathy speech. Here is the beginning of his tribute:

个I HATE you, God. I HATE you (pause: $1 \mathrm{~s}$ )

$\downarrow$ Oh don't tell me you haven't said the words before. I know you have. We all have, if you've felt so crushing a loss. (.) There are two parents with us today who know the pain, the most terrible hurt of all (.) losing a child before her time. If Dean and Leanne were to stand up right now and scream those awful words of hate, could we blame them? I couldn't. At least their hatred I can understand. I can grasp it, but God's wantonness, his cruelty, I can't even begin to- (breaking off) $(1.3,29: 27-30: 17)^{20}$

Frank starts with an opening sentence that is bound to capture his audience's attention as it sounds quite daring in God's very house. But the boldness of the assertion ('I hate you God') is a negative politeness strategy (as charted by Brown and Levinson, 1987) that consists in 'impersonalizing' the conflictual situation by addressing God rather than the bereaved (a more personal 'you' would have made the address too direct), thus apparently distancing Speaker and Hearer (the parents)

\footnotetext{
20 See the transcription symbols at the end of the paper.
} 
from Frank's real face-threatening intent (make the parents drop the charges). Attending to what the couple may feel and think, he goes as far as voicing out loud their potential inner shameful thoughts at a time of unfair loss, taking everyone else as witness in a rhetorical question ("could we blame them? I couldn't"). He then adopts a positive politeness strategy consisting in "claiming common ground" by showing he has a common history of loss with them, trying to awaken some 'ingroup' empathy:

My father dropped dead of a heart attack at the age of 43,43 years old, and when he died, I looked up to God and I said those words, because my father was so young, so full of life, so full of dreams. Why would God take him from us? /.../21 I wept, I screamed, "WHY, God, how can I not HATE you when you steal from me the person I most love and admire in this world? (.) I don't understand it, and I hate you for it" (1.3, $30: 24-30: 40 ; 30: 56-31: 13)$.

By referring to his own personal pain and experience (using the personal pronoun "I"), Frank brings himself on the same level as Dean and Leanne who have previously blamed him for showing mere 'political' condolences. He is trying to "seek agreement" by sharing a personal painful event with the hope that this revelation will open the parents' heart and reduce the affective distance between them. Relying on the 'reciprocity principle' according to which sharing information usually brings the Other to open up and give back,22 Frank surreptitiously tries to create a 'sense of obligation' in his 'opponents' with whom he attempts to build alignment, assuming reciprocity of empathy. Of course, this manipulative use of politeness strategies is purely strategic as can be read in the following aside where he confesses distorting the truth to suit the necessity of the moment:

Truth be told, I never really knew him [my father] or what his dreams were. He was quiet, timid, almost invisible. My mother didn't think much of him. My mother's mother hated him. The man never scratched the surface of life. Maybe it's best he died so

\footnotetext{
21 The deleted passage marked /.../ corresponds to the aside that is transcripted further down.
}

22 See Garcia Gómez (2008:75)'s study of its use in violent talk shows. 
young. He wasn't doing much but taking up space. But that doesn't make for a powerful eulogy now, does it? $(1.3,30: 40-30: 56)$

The next step in Frank's well-prepared eulogy is a return to God and the scriptures. He goes on with the impersonalization strategy by '(re)personalizing' the event in the name of God (who conveniently cannot reply). Linguistically this is done by using a proverb from the bible that serves as an argument of authority behind which Frank can hide. Hoisting up the responsibility to a higher level, he turns what could be a FTA (stop blaming me) into a much less face-threatening "general rule" (negative politeness strategy) that enables him to dissociate Speaker (and Hearer) from the event:

The Bible says in proverbs, "Trust in the Lord with all your heart and lean not on your own understanding". Lean NOT on your own understanding. God is telling us to trust him, to love him despite our own ignorance. After all, what is faith (.) if it doesn't endure when we are tested the most? We will never understand why God took Jessica or my father or anyone. And while God may not give us any answers, he has given us (.) the capacity for love. Our job is to love him without questioning his plan. So I pray to you, dear Lord, I pray to you to help strengthen our love for you and to embrace Dean and Leanne with the warmth of your love in return. And I pray that you will help us fend off hatred so that we may all truly (.) trust in you with all our hearts and lean NOT on our OWN understanding. Amen. (1.3, 31:19 - 32:42)

Through a general saying that is hardly questionable for believers given its source, he asks them to forget what they think (or intend to do) and leave it up to God, whatever his unknown, incomprehensible design may be. Not to do so would make them unbelievers and sinners ("what is faith if it doesn't endure when we are tested the most?").

Frank here exploits his opponents' 'weak spots' (their belief in God) to get out of the tricky situation. Meanwhile he protects his own face - he does not apologize or incur a debt for instance. As I have argued, he uses double indirectness (addressing the church audience rather than addressing directly the couple and impersonalizingcum-repersonalising the debate using God as the overarching addressee). He thus can reduce the affective distance (using positive politeness as "social accelerator" in Brown and Levinson's words [1987:103]) and refrain from directing the couple's 
decision in too obvious a way (using negative politeness to put a break on imposition). But meanwhile, by manipulatively exploiting politeness tactics, he does restrict the couple's options and indirectly "coerces" them into agreeing with him, by respecting God's plan without looking for a human explanation.

Another strategy that is very often used by Frank in the series consists in playing on people's ambition through their self-esteem. Picturing what the future holds for them, he voices out loud their internal desires they may never have dared bring to the surface. Trying to make Bob Birch (Speaker of the House of Representatives in the first season) choose Womack, Congressman from Missouri's $5^{\text {th }}$ district and leader of the Black Causus, as the next majority leader, Frank uses his well-worn technique of 'subworld' fabrication (Werth, 1999) through which he plants seeds of an alternative 'imaginary' world in his targets' minds. This is an Other-directed strategy (fulfilling face wants) which enables him to divert his targets' attention away from his own egoistic purposes. Bringing Birch to envision what he could benefit from Womack's nomination, Frank uses a positive face strategy: "And I have to say appointing the first African-American leader, why, this isn't a bad legacy to have" (1.4). Showing that such decisions can enhance the Other by throwing positive light on them, he abides by Leech's politeness strategies (such as M1 'give a high value to O's wants'). What Leech calls the maxim of 'generosity' is in fact manipulatively used to serve the generous donator as much as his victims, presenting what is highly self-interested as opportunities for them in a most deceitful way.

\section{3 (Fake) Self-Face Threatening Acts}

Another strategy that has the same aim of furthering personal interests is the one using what could be construed, in Chen's (2001) words, as a voluntary Self-Face Threatening Act (SFTA), that is an act which, "if done without redress, will threaten [the Speaker's] own face" (Chen, 2001:95). Indeed, Frank and Claire Underwood are ready to do anything to get to their ends, even if this implies committing speech acts that incur a cost to the Self. Having been raped in her freshman year by a classmate who is today General Dalton McGinnis, Claire has spent a lot of energy working on a military assault bill (McGinnis has raped other marines) and is determined to see this bill pass through the House. She has to fight over it with the ex-military Jackie Sharp 
who is the Deputy House Minority Whip. As Claire perceives she is not willing to support the bill, she decides to drop the battle she had engaged with her because Jackie is a key asset in the Underwoods' overarching final goal (the presidency). She thus decides to offer her an apology. Apologies, as Grainger and Harris (2007:1) indicate is "perhaps the example par excellence of politeness at work". Offering an apology is a way to rectify the harm that has been done, it is thus a gain for the Other's negative face (who is reinstated in her want to remain unimposed), but it is also a potential SFTA as an apology amounts to admitting a fault and asking for forgiveness. Claire does not hesitate to pay the price of an apology (with the Self effacement it imposes) in order to resolve a conflict that could hamper her overall life goal.

Of course, her apology is not sincere and therefore, in Austinian terms (1962), 'infelicitous': it is a manipulative use of politeness that consists in 'erasing' past conflicts with $\mathrm{O}$ and starting over. It is thus a trust-restoring strategy rather than a heart-felt attempt at "putting right" the harm done (Holmes, 1998:217). This pseudoapology, disconnected as it is from any affect, is parasitic on the normal working of an apology: the linguistic interpretation and representation of the apology is indeed absolutely standard, it is in view of the 'ulterior motive' that it becomes manipulative. Rather than being a genuine gift offered to the Hearer, it is clearly a temporary cost for the Speaker in view of a later greater gain. The act of apologizing that usually involves Self-effacement by giving a "high value to Other's feelings" (Leech's [2014:91] Maxim 9 of sympathy) must be reinterpreted in this context as an instrumental SFTA disguising as a polite 'repair act', the Other being kept out of the Speaker's broader personal agenda. In this sense, the fake SFTA can be seen as congruent with Goffman's (1967:314) perspective when he states that the threat to one's own face can be strategically considered if a higher gain is to be obtained by it. 23

\subsection{Giving a high value to Self: strategic enticing}

\footnotetext{
${ }^{23}$ Ermida (2006:848-9) gives the following examples in this perspective: "belittle yourself as to make others praise you", or "safely offend someone who, as far as you can foresee, will forbearingly accept your fake apologies".
} 
Leech's 10 maxims that compose his General Strategy of Politeness (GSP) (2014:91) are oriented towards granting a high value to O's wants/qualities/opinions and feelings and in inverse proportion giving 'low value' to S's wants/qualities/opinions and feelings. The only 'high value' that is given to $S$ is in her obligation to $\mathrm{O}$ (Maxim 5). However, the art of influencing people can resort to means that in Leech's theoretical framework would amount to impoliteness: the Self can indeed be enhanced so that the positive image reflects back on the Other and make her want to comply with the Self's plan. Chilton (1990:210) points this out when he shows that the performance of speech acts like orders or requests "can be interpretable as an expression of power and status". The example below has to do with a similar concern for the "presentation of self" in Goffman's sense ${ }^{24}$, that is a concern for the preservation of one's own "Self image" and the impact it can foster on the Other's own sense of Self.

The extract will help understand how Speaker's Self-enhancement can paradoxically boost the Other's Self-esteem. Peter Russo is campaigning for the seat of Governor in Pennsylvania, helped by Vice-President Jim Matthews who was a former governor of that state. Peter complains to Frank Underwood about Matthews's hampering Peter's campaign instead of promoting it. Frank answers that using rational means will have no effect, what Peter must do is 'tap into' Jim's sense of selfworth, i.e. to respond to the image of himself the VP wants to see reflected in Peter's eyes:
Peter:
We have fundamentally different views.
Frank: Well look you're not going to be able to change his ideology, but dig deeper. Jim is a proud man. Tap into that pride.
Peter: I just wish he was gone.
Frank: Well, you do whatever you think best. But whatever it is you decide, be firm and stand up for yourself. He'll respond to that at least. $(1.9,22: 01$ $-22: 18)$

The advice given to Peter consists in pushing forward firm Self presentation with the hope it will have an impact on Jim's own Self image and bring him to change his

\footnotetext{
24 See Bargiela-Chiappini (2003:1458-1463) for a review of Goffman's definitions of face and self-presentation.
} 
attitude towards Peter. In the following exchange with the VP, Peter intends to project the image of a determined man, reaching a point where he performs impolite speech acts:

Peter: (in a raised voice) My point is you kept going. You hit and you proved everyone wrong. Like it or not, it's my name on the ticket this time, and I got the shot, and I'm gonna prove everyone wrong. Just like you did. Including you, sir. $\downarrow$ I would like your support, but if you won't give it, fine (.) it won't stop me.

Matthews: (pause: 2s)

You think it's easy for me to be here? I left the Governor's mansion right in my prime. To be what? vice president. I thought that was a step up. But you know what? I don't have a fucking shred of real influence. I'm trotted around like a goddam mascot, this is my home state.

Peter: I'm offering you influence, sir. l'd like your guidance and your expertise. (.) But if that's not on the table, then, (.) with all due respect, Mr Vice President, you should head back to Washington. (Peter leaving the room) $(1.9,35: 32-36: 25)$

In his bold move, Russo is both polite and impolite. He presents himself as a candidate that is the worthy successor of Jim Matthews who also fought his way to success in the past, thus using both Self- and Other-face flattering acts, as Peter tries to find a community of face needs and wants with Matthews: "I'm gonna prove everyone wrong just like you did". But praise of the Other ("Id like your guidance and expertise") is accompagnied with on record, hardly mitigated, face-threatening acts. The commissive ('I'm offering you influence') is indeed boldly associated with a threat ('But if that's not on the table, then, well with all due respect, Mr Vice President, you should head back to Washington').

These impolite moves that seem to imply a cost to $\mathrm{O}$ (as it gives a high value to O's obligation to $S$, in contradistinction with Leech's polite maxim of obligation) as well as a potential cost to $S$ (it being a risky SFTA with a potentially negative outcome) is a manipulative tactic used by Peter to bring the VP to act in the right direction: the Speaker's goal is to grant himself a Self image that will be appealing to $O$ and reflect positively on O's positive face, in a full reversal of Leech's GSP. Leech's focus on $O$ (even if it can reflect on the Self in return) cannot account for such hybrid manipulative moves that are both polite and impolite, the double-headed 
strategy being here triggered by the alternative offered to the VP: endorse fully or leave. In this particular context, impoliteness does not aim at attacking the face of the Other ("face attack" being quite central to impoliteness research, see Culpeper et al, 2003:1554) but at faking to attack it through an assertion of power with the hope of 'seducing' $O$ into coming round. Matthews gives vent to his feelings of being treated unfairly in the White House as he is undervalued and kept away from fundamental decisions, thus feeling deprived of what Spencer-Oatey (2002:540) calls his "sociality rights" (corresponding to what a person claims he is entitled to in his interaction with others, i.e. a certain amount of consideration from and association with others). Peter's bold speech acts consist in giving him back those rights and the self-esteem that goes with them.

What this fictional example shows is that impoliteness can be used manipulatively: in compliance with Peter's covert aim, Matthews reinterprets Peter's bald/impolite threat as a compliment to his (proud) ego. Impoliteness - here coupled with a polite strategy offered for the preferred line of action - can thus be manipulatively used not to create but paradoxically to bridge distance and resolve conflict.

\section{Conclusion}

The aim of this paper was to offer a theoretical rebalance in pragmatic theories that have been biased in markedly emphasizing the Other's face needs and wants in a cooperative perspective. I have demonstrated that MD is parasitic both on the Cooperative Principle and politeness strategies as inventoried in the literature but requires taking into consideration Speakers' (overt and covert) social goals as these may have an influence on how politeness is instrumentally used. I have shown that there are at least three forms that Manipulative Discourse can take:

1. Falsely enhancing the Other and/or impersonalizing the conflict, the better to conceal selfish intentions (violation of the CP / exploitation of the GSP)

2. Consenting to a cost to Self in view of a later higher gain (insincere SFTA)

3. Enhancing Self image in order to entice $O$ into agreement (hybrid form of (im)politeness: positive politeness as well as impolite moves such as Self-face flattering acts and impingement on O's negative face) 
All the tactics aim at positioning the Other, coercing her into taking alignment with the Speaker for an immediate or postponed benefit (for similar strategies of coercion and delegitimation of the Other, see Stewart, 2008). The use of politeness definitely aims at 'avoiding conflict' since the goal is not to antagonize $\mathrm{O}$ (completely). However the kind of politeness strategies that are deployed in MD proves to be much more hybrid than Brown and Levinson's demarcations intimate. In particular, MD is predicated on an equal consideration of Self's and Other's face needs and wants.

One could certainly object that the fictional corpus used in this paper cannot be said to reflect real spontaneous discourse. I would first argue with Richardson (2010:61) that although constructed speech does not echo the hesitations, repetitions and sometimes indistinctiveness of daily conversation, it mirrors the ordinary functioning of language used to mediate social interactions in everyday life. I would then contend that MD is not limited to fictional practice. If one thinks about it, manipulative tactics are not hard to find at work in our daily interactions. Nevertheless further research on spontaneous discourse will need to confirm these theoretical findings on what has often been wrongly regarded as "failures" of cooperative communication.

Acknowledgment: This work was supported by the Institut Universitaire de France (IUF). I would like to express warm thanks to the two reviewers for their time and extremely insightful remarks.

Transcription conventions

(.) slight pause

(pause: $\mathrm{n}$ seconds) longer pause with duration noted in number of seconds

Capital letters strong salient emphasis

$\downarrow$ marked pitch leap downwards

$\uparrow$ marked pitch rise

? marked rising intonation (not necessarily question)

, slightly rising intonation

. marked falling intonation (not necessarily statement)

“ marked as 'quoted' by intonation/voice quality

() includes transcriber's comments

I...I indicates suppressed speech by transcriber 


\section{References}

Agha, Asif ,1997. Tropic aggression in the Clinton-Dole presidential debate. Pragmatics 7, 461-97.

Arundale, Robert B., 2010. Constituting face in conversation: Face, facework, and interactional achievement. Journal of Pragmatics 42, 2078-105.

Attardo, Salvatore, 1997. Locutionary and perlocutionary cooperation: The perlocutionary cooperative principle. Journal of Pragmatics 27, 753-779.

Austin, John Langshaw, 1962. How to Do Things with Words. Harvard University Press, Cambridge, Mass.

Bargiela-Chiappini, Francesca, 2003. Face and politeness: new (insights) for old (concepts). Journal of Pragmatics 35, 1453-1469.

Baron, Marcia, 2003. Manipulativeness. Proceedings and Addresses of the American Philosophical Association 77(2), 37-54.

Beauvois, Jean-Léon, 2011. Les influences sournoises. Précis des manipulations ordinaires. Bourin, Paris.

Brown, Penelope \& Levinson, Stephen C., 1987. Politeness. Some Universals in Language Usage. Cambridge University Press, Cambridge.

Capone, Allessandro, 2001. The semantics/pragmatics interface from different points of view. Journal of Pragmatics 37(2), 445-450 (review of Turner, K. (Ed.)).

Chapman, Siobhan, 2011. Pragmatics. Palgrave Macmillan, Basingstoke.

Chen, Rong, 2001. Self-politeness: A proposal. Journal of Pragmatics 33, 87-106.

Cholbi, Michael, 2014. The implications of ego depletion for the ethics and politics of manipulation. In: Coons C. \& Weber M. (Eds.), Manipulation. Theory and Practice. Oxford University Press, Oxford, pp. 201-20.

Chilton, Paul, 1990. Politeness, politics and diplomacy. Discourse and Society 1(2), 201-224.

Cialdini, Robert B., Vincent, Joyce E., Lewis, Stephen K., Catalan, Jose, Wheeler, Diane, \& Darby, Betty Lee, 1975. Reciprocal concessions procedure for inducing compliance: The door-in the face technique. JPSP 31, 206-215.

Cialdini, Robert B., 1984. Influence: How and Why People Agree to Things, first ed. Morrow, New York.

Cialdini, Robert B., 2001. Influence: Science and Practice, fourth ed. Allyn \& Bacon, Boston.

Clément, Fabrice, 2006. Les mécanismes de la crédulité. Librairie Doz, Paris.

Culpeper, Jonathan, Bousfield, Derek, Wichmann, Anne, 2003. Impoliteness revisited: with special reference to dynamic and prosodic aspects. Journal of Pragmatics 35, 1545-79. 
Culpeper, Jonathan \& Terkourafi, Marina, 2017. Pragmatic approaches to (im)-politeness. In: Culpeper, J., Haugh, M. \& Kádár, D.Z (Eds.), The Palgrave Handbook of Linguistic (Im)politeness. Palgrave Macmillan, Basingstoke.

Danler, Paul, 2005. Morpho-syntactic and textual realizations as deliberate pragmatic argumentative linguistic tools? In: Saussure, L. de \& Schulz, P. (Eds.), Manipulation and Ideologies in the Twentieth Century. John Benjamins Publishing, Amsterdam, Philadelphia, pp. 45-60.

Bousfield, Derek, 2008. Impoliteness in Interaction. John Benjamins Publishing, Amsterdam, Philadelphia.

Ermida, Isabel, 2006. Linguistic mechanisms of power in Nineteen Eighty-Four. Applying politeness theory to Orwell's world. Journal of Pragmatics 38, 842-862.

Fairclough, Norman, 1989. Language and Power. Longman, London.

Festinger, Leon, (1957). A Theory of Cognitive Dissonance. Stanford University Press, Stanford, CA.

Fracchiolla, Béatrice, 2008. L'attaque courtoise: de l'usage de la politesse comme stratégie d'agression dans le débat Sarkozy-Royal du 2 mai 2007. Actes JADT'2008 - 9èmes journées internationales d'analyse statistique des données textuelles, 12-14 March 2008, Lyon.

Fracchiolla, Béatrice, Romain, Christina, Moïse, Claudine \& Auger, Nathalie, 2013. Violences verbales. Analyses, enjeux et perspectives. Presses Universitaires de Rennes, Rennes.

Freedman, Jonathan L., \& Fraser, Scott C., 1966. Compliance without pressure: The foot-inthe-door technique. JPSP 4, 196-202.

Galasiński, Dariusz, 2000. The Language of Deception. A Discourse Analytical Study. Sage Publications, Thousand Oaks, London and New Delhi.

García Gómez, Anotonio, 2008. Attitude-behaviour discrepancy and cognitive dissonance: Tactics for enhancing compliance in persuasive discourse. Odisea 9, 67-81.

Goffman, Erving, 1967. On face-work. In: Interaction Ritual. Essays on Face-to Face Behavior. Pentheon Books, New York, pp. 5-45.

Goldman, Morton, Kiyohara, Odette, \& Pfannensteil, Dorothy, 1985. Interpersonal touch, social labeling and the foot-in-the-door effect. The Journal of Social Psychology 152, $143-$ 147.

Gorin, Moti, 2014. Towards a theory of interpersonal manipulation. In: Coons, C. \& Weber, M. (Eds.), Manipulation. Theory and Practice. Oxford University Press, Oxford, pp. 73-97.

Grainger, Karen and Harris, Sandra, 2007. Introduction. Special issue on apologies. Journal of Politeness Research 3 (1), 1-9. 
Grice, Herbert Paul, 1975. Logic and conversation. In: Cole, P. \& Morgan, J.L. (Eds.), Syntax and Semantics 3, 'Speech Acts'. Academic Press, New York, pp. 41-58.

Grice, Herbert Paul, 1989. Study in the Way of Words. Harvard University Press, Cambridge, MA.

Gu, Yueguo, 1990. Politeness phenomena in modern Chinese. Journal of Pragmatics 14(2): 237-258.

Gu, Yueguo,1993. Pragmatics and rhetoric: A collaborative approach to conversation. In: Parret, H. (Ed.), Pretending to Communicate. Walter de Gruyter, Berlin, New York, pp. 173-95.

Guéguen, Nicolas, 2011. Psychologie de la manipulation et de la soumission, revised ed. Dunod, Paris.

Guérin, Charles, Siouffi, Gilles and Sorlin, Sandrine, 2013. Le Rapport éthique au discours: histoire, pratiques, analyses / Ethics and Discourse in Historical Perspective: Practice \& Theory. Peter Lang, Bern.

Haugh, Michael, 2007. The co-constitution of politeness implicature in conversation. Journal of Pragmatics 39, 84-110.

Holmes, Janet and Stubbe, Maria, 2014. Power and Politeness in the Workplace. Routledge, London, New York.

House of Cards, (2013-), Season 1 (13 episodes, released 1 February 2013), Season 2 (13 episodes, released 14 February 2014), Season 3 (13 episodes, released 27 February 2015), Network: Netflix. Writers: Beau Willimon, Michael Dobbs, Andrew Davies (among others). Directors: Robin Wright, David Fincher, James Foley, Joel Schumacher, Charles McDougall.

Habermas, Jürgen, 1987. Théorie de l'agir communicationnel. Tome 2. Pour une critique de la raison fonctionnaliste, trans. Schegel. Fayard, Paris.

Habermas, Jürgen, 2006. Idéalisations et communication: Agir communicationnel et usage de la raison, trans. Bouchindhomme. Fayard, Paris.

Herman, Thierry and Oswald, Steve (Eds.), 2014. Rhétorique et cognition / Rhetoric and Cognition. Perspectives théoriques et stratégies persuasives. Theoretical Perspectives and Persuasive Strategies. Peter Lang, Bern.

Holmes, Janet, 1998. Apologies in New Zealand English. In: Cheshire, J. \& Trudgill, P. (Eds.), The Sociolinguistics Reader: Gender and Discourse 2. Arnold, London, pp. 201239.

Joule, Robert Vincent \& Beauvois, Jean-Léon, 2002. Petit traité de manipulation à l'usage des honnêtes gens. Presses Universitaires de Grenoble, Grenoble. 
Kecskes, Istvan, 2010. The paradox of communication: Socio-cognitive approach to pragmatics. Pragmatics \& Society 1(1), 50-73.

Kerbrat-Orecchioni, Catherine, 2010. L'impolitesse en interaction: Aperçus théoriques et étude de cas. Lexis Special 2, Theoretical Approach to Linguistic (Im)politeness, 35-60. http://lexis.univ-Iyon3.fr/IMG/pdf/Lexis_special_2_-_Kerbrat-Orecchioni.pdf, date accessed 5 November 2015.

Leech, Geoffrey, 1983. Principles of Pragmatics. Longman, London.

Leech, Goeffrey, 2014. The Pragmatics of Politeness. Oxford University Press, Oxford.

Levinson, Stephen C., 2006. On the human 'interaction engine'. In: Enfield, N.J., Levinson, S. C. (Eds.), Roots of Human Sociality. Oxford, Berg, pp. 39-69.

Locher, Miriam A. and Watts, Richard J., 2005. Politeness theory and relational work. Journal of Politeness Research 1, 9-33.

Lumsden, David, 2008. Kinds of conversational cooperation. Journal of Pragmatics 40, 18961908.

Maillat, Didier \& Oswald, Steve, 2009. Defining manipulative discourse: The pragmatics of cognitive illusions. International Review of Pragmatics I, 348-370.

Maillat, Didier, 2013. Constraining context selection: On the pragmatic inevitability of manipulation. Journal of Pragmatics 59, 190-199.

Maillat, Didier, 2014. Manipulation et cognition: un modèle pragmatique. In: Herman, T. and Oswald, S. (Eds.), Rhétorique et cognition / Rhetoric and Cognition. Perspectives théoriques et stratégies persuasives / Theoretical Perspectives and Persuasive Strategies. Peter Lang, Bern, pp. 69-88.

Masip, Jaume, Garrido, Eugenio and Herrero, Carmen, 2004. Defining deception. Anales de psicología 20(1), 147-71.

McCornack, Steven A,1992. Information manipulation theory. Communication Monographs $59,1-16$.

Milgram, Stanley, 1963. Behavioral study of obedience. Journal of Abnormal and Social Psychology 67, 371-378.

Mills, Claudia, 1995. Politics and manipulation. Social Theory and Practice 21(1), 97-112.

Mooney, Annabelle, 2004. Co-operation, violations and making sense. Journal of Pragmatics 36, 899-920.

O'Driscoll, Jim, 1996. About face: a defence and elaboration of universal dualism. Journal of Pragmatics 25, 1-32.

O'Keefe, Daniel J., 2002. Persuasion: Theory and Research. $2^{\text {nd }}$ ed. Sage, Thousand Oaks, London, New Dehli. 
Pfister, Jonas, 2010. Is there a need for a maxim of politeness? Journal of Pragmatics 42, 1266-1282.

Reboul, Anne, 1994. The description of lies in speech acts theory. In: Parret, H. (Ed.), Pretending to Communicate. Walter de Gruyter, Berlin, New York, pp. 292-98.

Richardson, Kay, 2010. Television Dramatic Dialogue. A Sociolinguistic Study. Oxford University Press, Oxford.

Sarangi, Srikant K and Slembrouck, Stefaan, 1992. Non cooperation in communication: A reassessment of Gricean Pragmatics. Journal of Pragmatics 17, 117-154.

Saussure, Louis (de), 2005. Manipulation and cognitive pragmatics. Preliminary hypotheses. In: Saussure, L. (de) and Schulz, P. (Eds.), Manipulation and Ideologies in the Twentieth Century. John Benjamins Publishing, Amsterdam, Philadelphia, pp. 113-145.

Saussure, Louis (de), 2014. Présuppositions discursives, assertion d'arrière-plan et persuasion. In: Herman, T. \& Oswald, S. (Eds.), Rhétorique et cognition / Rhetoric and Cognition. Perspectives théoriques et stratégies persuasives / Theoretical Perspectives and Persuasive Strategies. Peter Lang, Bern, pp. 279-311.

Saussure, Louis and Schulz, Peter J. (Eds.), 2005. Manipulation and Ideologies in the Twentieth Century. John Benjamins Publishing, Amsterdam, Philadelphia.

Scanlon, Thomas, 1998. What We Owe to Each Other. Belknap, Cambridge, MA.

Searle, John, 1998. Mind, Language and Society: Philosophy in the Real World. Basic Books, New York.

Sifianou, Maria, 2012. Disagreements, face and politeness. Journal of Pragmatics 44, 15541564.

Smith, David E., Gier, Jospeh A. \& Willis, Frank N., 1982. Interpersonal touch and compliance with a marketing request. Basic and Applied Social Psychology 3(1), pp. 3538.

Sorlin, Sandrine, 2016. Language and Manipulation in House of Cards. A Pragma-Stylistic Perspective. Palgrave Macmillan, Basingstoke.

Spencer-Oatey, Helen, 2002. Managing rapport in talk: Using rapport sensitive incidents to explore the motivational concerns underlying the management of relations. Journal of Pragmatics 34, 529-45.

Spencer-Oatey, Helen, 2007. Theories of identity and the analysis of face. Journal of Pragmatism 39, 639-56.

Spencer-Oatey, Helen, 2008. Introduction. In: Spencer-Oatey, H. (Ed.), Culturally Speaking. Culture, Communication and Politeness Theory. Bloomsbury: London, New Delhi, New York, Sydney, pp. 1-8. 
Spencer-Oatey, Helen, 2011. Conceptualising the "relational" in pragmatics: Insights from metapragmatic emotion and (im)politeness comments. Journal of Pragmatics 43, 3565-78.

Sperber, Dan and Wilson, Deirdre, 1995. Relevance: Communication \& Cognition, second ed. Blackwell, Oxford.

Thaler, Richard H and Sunstein, Cass R., 2008. Nudge: Improving Decisions about Health, Wealth, and Happiness. Yale University Press, New Haven.

Stewart, Miranda, 2008. Protecting speaker's face in impolite exchanges: the negotiation of face-wants in workplace interaction. Journal of Politeness Research 4, 31-54.

Van Dijk, Teun A., 2006, Discourse and manipulation. Discourse \& Society 17(3), 359-83.

Van Eemeren, Frans H., 2005. Foreword: Preview by Review. In Saussure, L (de) and Schulz, P. (Eds.), Manipulation and Ideologies in the Twentieth Century. Amsterdam, Philadelphia: John Benjamins Publishing, pp. ix-xv.

Van Eemeren, Frans H. \& Grootendorst, Rob, 2004. A Systematic Theory of Argumentation: The Pragma-Dialectical Approach. Cambridge University Press, Cambridge.

Werth, Paul, 1999. Text Worlds: Representing Conceptual Space in Discourse. Longman, London.

Wilkinson T. M., 2013. Nudging and manipulation. Political Studies 61, 341-355.

Wood, Allen W., 2014. Coercion, manipulation, exploitation. In: Coons, C. and Weber, M. (Eds.), Manipulation. Theory and Practice. Oxford University Press, Oxford, pp. 17-50. 